\title{
Health consequences of vitamin D deficiency in the human body
}

Paweł Glibowski ${ }^{1}$, Katarzyna łłowiecka², Karolina Środek ${ }^{1}$

1'Department of Biotechnology, Microbiology and Human Nutrition, Faculty of Food Science and Biotechnology, University of Life Sciences in Lublin, Poland

Abstract $\quad{ }^{2}$ Department of Food and Nutrition, Faculty of Pharmacy, Medical University in Lublin, Poland

Vitamin D is extremely important for the proper functioning of the body. The most commonly known role of vitamin D is its participation in regulation of calcium-phosphate metabolism and bone mineralization. This role is crucial in the prevention of rickets in children and osteoporosis in the elderly. In recent years, numerous studies have confirmed the pleiotropic effects of vitamin D. Proper vitamin D levels in blood have a positive effect on overall health, thus reducing the risk of many diseases. Vitamin D plays, inter alia, a positive role in some diseases of the gastrointestinal tract (inflammatory bowel disease), nervous system (Parkinson disease, Alzheimer disease), and cardiovascular disease (atherosclerosis). Additionally, its positive protective effect in the case of neoplastic and immunological diseases has been noted. Some studies also confirm the relationship of vitamin D deficiency to obesity and depression. In the event of these diseases, it is possible to prevent disease and support the process of treatment by maintaining appropriate levels of 25(OH)D in the blood. Besides, sufficient blood vitamin D levels reduces the risk of developing respiratory tract infections and suppresses cytokine storm, which is responsible for most COVID-19 deaths.

The aim of the study was to present the current state of knowledge regarding the role of vitamin $D$ in the human body, especially in the context of the impact of its abnormal level on the development of various diseases.

\section{INTRODUCTION}

Vitamin $D$ is a fat-soluble vitamin. It is formed in the human body under the influence of sunlight. Besides this mechanism, the source of this vitamin is food. Vitamin D was discovered in 1918. Initially, it was considered only in terms of its impact on the skeletal system and the phosphate-calcium balance. Over time, however, the positive effects of its influence on other organs, tissues, and systems of the human body were discovered. Numerous studies show the important role of vitamin $D$ in the functioning of the circulatory, immune, and nervous systems [1, 2, 3, 4]. This vitamin is also credited with a beneficial effect on mental health, including the prevention of depression $[5,6]$. The most promising area of research is the anti-carcinogenic effect of vitamin $D[2,7]$. Further research is being carried out to prove its effect on other systems of the human body. As a result of intensified research and new reports on vitamin $D$ in recent years, the popularity of supplements containing it has surged. The increased popularity of supplements is also associated with preventive measures. As it turns out, a significant number of people suffer from vitamin $D$ deficiency, especially in the autumn and winter season [8]. However, diet supplementation with this vitamin should be carried out in a controlled manner, due to the reported adverse effects caused by overdosing [1, 9]. 


\section{Sources of vitamin D}

There are two types of sources from which the body can obtain vitamin D. The first are endogenous sources, where vitamin $\mathrm{D}$ is obtained by skin synthesis. Many studies show that $80 \%$ to $90 \%$ of vitamin D comes from the synthesis of 7-dehydrocholesterol present in the skin. The second are exogenous sources: food products and dietary supplements [10]. Food can provide no more than $30 \%$ of the daily vitamin $D$ requirement [2].

For healthy people exposed to the sun with uncovered forearms and lower legs for at least 15 minutes from 10 am to $3 \mathrm{pm}$ without sunscreen during the period from May to September at no higher than approximately 55 degrees latitude, supplementation is not necessary, although it is still recommended and safe. However, if these conditions are not met, supplementation is recommended. The supply of vitamin $D$ should be individually adjusted to each person, depending on various factors, such as age, body weight, sun exposure, diet, and the other factors of lifestyle [11].

\section{Vitamin D metabolism}

At the beginning of vitamin $D$ synthesis, it appears as provitamin $\mathrm{D}$, that is, 7-dehydrocholesterol, a substance present in the epidermis. UVB rays with a wavelength of 290-315 nm convert 7-dehydrocholesterol into cholecalciferol. This compound is then transported to the liver. There, with the participation of 25-hydroxylase (CYP27A1, CYP3A4), the resulting compound is converted to calcifediol (25-hydroxycholecalciferol or calcidiol). This vitamin $\mathrm{D}$ prohormone, abbreviated as $25(\mathrm{OH}) \mathrm{D}_{3}$, travels through the bloodstream to the kidneys, where it is converted by 1 - $\alpha$-hydroxylase into calcitriol $\left(1,25(\mathrm{OH})_{2} \mathrm{D}\right)$, which is the active form of vitamin $\mathrm{D}$. This reaction is stimulated by parathyroid hormone (PTH). Calcitriol is released back into the blood [12]. The symbols, names, and functions of vitamin D metabolites are summarized in Table 1.

The concentration of vitamin $D$ in the human body depends on several factors. These factors include diet, supplementation, genetic predisposition (skin pigmentation), cultural habits (dress code affecting body exposure), and geographic conditions (latitude). There are about 40 vitamin $\mathrm{D}$ metabolites in the blood, which, to different degrees, reflect the actual concentration of vitamin $D$ in the body [13]. Vitamin $\mathrm{D}$ levels in the body can be determined by examining the level of the $25(\mathrm{OH}) \mathrm{D}$ metabolite in plasma. It is the most reliable exponent showing a good supply of vitamin $D$ because of the long half-life in plasma [14]. Using the $25(\mathrm{OH})$ $\mathrm{D}$ metabolite, and more specifically its 25 -monohydroxylated isoforms $25(\mathrm{OH}) \mathrm{D}_{3}$ and $25(\mathrm{OH}) \mathrm{D}_{2}$ (which is a metabolite of ergocalciferol - vitamin D of plant origin), it is possible to detect vitamin $\mathrm{D}$ deficiency or excess caused by improper supplementation [15].

The level of 25(OH)D in the blood fluctuates throughout the day; it has been shown that this variability is about $20 \%$ [16]. The concentration of vitamin $D$ in the blood also varies with the season and sun exposure. Clinical studies on the effectiveness of dermal synthesis of vitamin $D$ have shown that in people with light skin pigmentation, one minimal erythema dose (1 MED), that is, a dose of UV rays causing minimal skin erythema, leads to a 10 -fold increase in the concentration of vitamin $D_{3}$ in the blood serum due to the release of about $30 \mu \mathrm{g} \mathrm{D}_{3}$ from $1 \mathrm{~m}^{2}$ of body surface within 24 h. Elevated vitamin $D$ levels caused by exposure to the sun return to normal after a few days [17].

According to the latest recommendations, the normal concentration of 25(OH)D in the plasma ranges from 20 to $80 \mathrm{ng} / \mathrm{mL}$ depending on location and age. A concentration

Table 1. Symbols, names, and functions of vitamin D metabolites 
below $10 \mathrm{ng} / \mathrm{mL}$ is referred to as severe vitamin $D$ deficiency and above $100 \mathrm{ng} / \mathrm{mL}$ is considered toxic [11]. Severe deficiency can lead to the onset of rickets (especially in children), osteomalacia, myopathy, and hyperparathyroidism. The suboptimal concentration, that is, an inadequate supply of vitamin $D$, is characterized by reduced calcium absorption in the gastrointestinal tract and increased PTH, and sometimes by decreased bone mineral density [18]. Supplementation should occur in order to obtain and maintain optimum concentrations of vitamin $D$, which is 30 $50 \mathrm{ng} / \mathrm{mL}$ [11]. Vitamin D excess (hypervitosis) in the body is accompanied by hypercalcemia (too much calcium in the blood), hypercalciuria (increased urinary calcium excretion), and PTH suppression [15].

\section{The role of vitamin $D$ in the body}

Research on vitamin $D$ began in relation to its effects on bones. At the end of the 19th century, a disease called rickets emerged in Europe that caused muscle wasting, deformation of the legs and stunted growth in children. However, it was not until the 1930s that this disease began to be associated with vitamin $\mathrm{D}$ deficiency. Then, vitamin $\mathrm{D}$ was added to milk, which significantly reduced this problem [19]. Gradually, researchers began to discover many more areas where vitamin $\mathrm{D}$ can improve overall health and prevent disease.

The most important role of vitamin $D$ in the human body concerns the regulation of calcium and phosphorus metabolism, which is indispensable for the functioning of the skeletal system. Calcium is responsible, among other factors, for blood clotting and stabilizing blood pressure. It also contributes to the proper functioning of the brain, and is necessary for the transmission of important information between cells. Like calcium, most phosphorus (80-90\%) is found in bones. The rest is in the blood and body fluids. The main function of phosphorus is to combine with calcium to mineralize bone material. In addition, phosphorus is part of the DNA, and is also responsible for the body's use of energy (as ATP, CTP, GTP) from carbohydrates, fats and proteins. Vitamin $D$ regulates the interaction of calcium and phosphorus; hence, it is essential for the proper development of the human skeleton from prenatal life until the end of the growth period. It creates the right conditions for bone mineralization, which is extremely important in the development of children, and also has an impact on the proper growth and structure of dentition. In the elderly, vitamin $D$ protects against bone fracture [12].

Vitamin D affects the bone cells both directly and indirectly through the intestine, kidneys, and parathyroid glands. The active form of vitamin $D$ is a hormone that directly impacts bone cells. Otherwise, it acts indirectly on the bone by regulating calcium metabolism and the expression of the parathyroid hormone. The active form of vitamin D stimulates the differentiation of osteoblasts, determines the proper mineralization of the osteoid, stimulates the formation and maturation of osteoclasts, and regulates the expression of numerous genes in osteoblasts and osteoclasts [20]. Regulation of gene expression for proteins involved in epithelial calcium absorption causes an increase in calcium absorption in the gastrointestinal tract and reabsorption of this element in the renal tubules, which ensures the correct concentration of calcium in the blood serum and the proper mineralization of bone tissue. By inhibiting PTH secretion, vitamin $D$ inhibits bone resorption [21]. For these reasons vitamin $D$ is necessary for the construction and proper functioning of the skeletal system, as well as for the prevention of many bone-related diseases such as, for example, osteoporosis [22].

Vitamin D plays an important role in the functioning of the immune system, which is responsible for protecting the body against viruses and bacteria. Vitamin $D$ in its active form has a positive effect on the body's autoimmune activity. Calcitriol prevents the activation and arming of $\mathrm{T}$ lymphocytes during autoimmunity, blocking their further production. Thus, adequate calcitriol levels stop T cells from attacking their own tissues [23].

One of the most important functions of vitamin $D$ is to prevent cancer. Research conducted by Grant and Garland confirm the relationship between exposure to UVB and reduced risk of cancer of the breast, colon, ovary, prostate, Hodgkin's lymphoma and non-Hodgkin's lymphoma [24]. There is also an interdependence between high vitamin $D$ levels in the blood and a lowered risk of cancer. People with $25(\mathrm{OH}) \mathrm{D}_{3}$ levels higher than $20 \mathrm{ng} / \mathrm{mL}$ have a $30 \%$ to $50 \%$ lower risk of developing prostate and colon cancer. The impact of the season of diagnosis on the mortality rate in patients with breast, prostate, and colon cancer is also known. Patients diagnosed in the autumn season have a $15 \%$ lower mortality compared to those diagnosed in winter, when the skin synthesis of vitamin $D$ is significantly limited [25]. There are several ways in which vitamin $D$ contributes to the prevention and treatment of cancer. Vitamin $D$ controls apoptosis: the process of destroying worn-out or damaged cells. It activates or deactivates certain genes and may cut off the blood supply to newly formed changes in the body, and can also help prevent metastases [2, 7].

Vitamin D also supports the heart and circulatory system. There is a correlation between vitamin $D$ levels and the incidence of heart disease. It was found that mortality from cardiovascular diseases increases according to distance from the equator or fewer days of sunshine per year. Additionally, the greatest number of patients die in winter, when the vitamin $D$ level is at its lowest [26]. Vitamin D contributes to inhibiting 
the development of ischemic heart disease by reducing inflammation and reducing insulin resistance [27].

Vitamin $D$ is used in the treatment of diabetes and obesity. Type I diabetes is caused by a malfunction of the immune system. Lack of vitamin $D$ causes an intensified autoimmune reaction, where pancreatic cells are destroyed, which results in the inhibition of the insulin secretion process. The development of type 2 diabetes is influenced, among other factors, by obesity, advanced age, and lack of physical activity. These factors are also inextricably linked with vitamin $D$ deficiency. This fact has been confirmed by research - people with lower levels of vitamin $D$ in the body were at risk of developing both type 1 and 2 diabetes [28]. The results of studies from recent years prove the influence of vitamin $D$ deficiency on the development of obesity. It is still unclear whether vitamin $D$ deficiency is directly related to the development of obesity, or only indirectly contributes to it [29].

Vitamin D also affects human mental health. Researchers are still trying to find a direct relationship between the effects of vitamin $\mathrm{D}$ deficiency and the development of depression [5]. People with 25(OH)D lower than $16 \mathrm{ng} / \mathrm{mL}$ show significantly more severe symptoms of depression than those with at least $16 \mathrm{ng} / \mathrm{mL}$ [30]. Vitamin $\mathrm{D}_{3}$ affects the functioning of the central nervous system. Supplementation with vitamin $\mathrm{D}_{3}$ in people with depressive disorders has an antidepressant effect. It may also positively affect the prevention of relapse of depression [31].

\section{Diseases related to excess of vitamin D}

It is impossible to reach a toxic concentration of vitamin D obtained from excessive skin synthesis. Any surplus is broken down into inactive metabolites. These are tachysterol, lunisterol, suprasteol, and 5,6-trans-vitamin $D_{3}$ [3]. However, excessive exposure to sunlight may contribute to the formation of skin cancer [32]. Although dietary intake of vitamin $D$ does not pose the risk of overdosing, uncontrolled use of supplements increases this risk [1,9].

The excess vitamin $D$ is stored in adipose tissue. In the event of a reduced supply of vitamin $D$, the body can use the reserves accumulated there. However, these resources cannot be used over a longer period because they are limited and last only a few months [10].

Due to the long half-life and storage of vitamin $D$ in the body, administration of its recommended dose may be nonstandard. Vitamin D may not necessarily be taken daily, it can be taken, for example, once or twice a week. However, it is important not to exceed 60,000 IU per dose $(1500 \mu \mathrm{g})$. The latest standards recognize 4000 IU per day as safe consumption. A toxic dose is considered to be more than
30,000 IU per day for more than 3 months [9]. Symptoms of the toxic concentration of vitamin $D$ in the body are hypercalcemia, abdominal cramps, constipation, vomiting, diarrhea, increased thirst, polyuria, skin itching, muscle pain, disorientation, and coma [1].

\section{Vitamin deficiency}

Vitamin D deficiency is a common problem. The most important reason for vitamin D deficiency is limited skin synthesis [33]. Moreover, deficiencies may result from reduced bioavailability of vitamin $D$ from the gastrointestinal tract, which may result in malabsorption and impaired metabolism as well as inability to use vitamin $D$ reserves accumulated in adipose tissue in obese people (vitamin $D$ sequestration in adipose tissue) [34]. Examples of diseases associated with malabsorption include celiac disease, inflammatory bowel disease (e.g., Leśniowski-Crohn disease, ulcerative colitis), and liver and pancreatic diseases (e.g., in people with cystic fibrosis) [10].

A diet low in vitamin $D$ sources may also lead to insufficient levels in the body. People consuming an improperly balanced diet that does not contain fatty fish or dairy products are prone to vitamin $D$ deficiencies. Vegetarians and vegans as well as people who eat macrobiotically, due to the low supply of foods rich in vitamin $D$ in these diets, are also at risk of deficiencies [35]. Also, in breastfed newborns, vitamin D deficiency may occur due to its low content in breast milk (20 IU/L) [36]. Deficiencies may also be the result of disturbed vitamin $D$ hydroxylation or excessive catabolism caused by pharmacotherapy [17].

Most symptoms of vitamin D deficiency are neglected or attributed to various other factors. Symptoms such as general weakness, persistent fatigue over a long time, muscle aches, lack of energy, motivation, and prolonged depression could be noticed. Seemingly trivial symptoms such as mood swings, insomnia, back pain, muscle weakness, headache, and hair loss may indicate a lack of vitamin $D$ in the body [37]. Children may also develop irritability, drowsiness, developmental delay, bone changes, and even fractures [38]. Low vitamin $\mathrm{D}$ concentration in the body may lead to clinical symptoms, including bone pain, muscle weakness, and low bone mass, which may result in the development of diseases such as osteomalacia, osteoporosis, and myopathy [39].

\section{Diseases related to vitamin D deficiency}

Due to the pleiotropic effects of vitamin D in the body, its deficiency can cause a variety of diseases. Maintaining the proper concentration of $25(\mathrm{OH}) \mathrm{D}$ in the blood is extremely important in the prevention of many diseases. For many years 
studies have emerged showing the influence of vitamin $D$ on the functioning of many systems of the human body. This knowledge may prevent the development of diseases through the early implementation of supplementation with vitamin $D$ [40]. The optimal concentration of $25(\mathrm{OH}) \mathrm{D}$ is indicated as an important factor in the prevention of osteoporosis and fractures, rickets and osteomalacia, as well as autoimmune diseases, including multiple sclerosis, type 1 diabetes or systemic lupus erythematosus, infectious diseases, including tuberculosis and influenza, cardiovascular diseases, neurocognitive disorders, including Alzheimer's disease, autism, pregnancy complications, type 2 diabetes, as well as reducing the incidence of cancer, improvement of survival and quality of life in the course of cancer diseases, and overall mortality [11].

\section{Cardiovascular diseases}

Studies regarding the pleiotropic activity of vitamin D carried out in recent years have confirmed the relationship of its deficiency with the occurrence of cardiovascular diseases. It has been observed that in patients with low vitamin $D$ levels in the blood, ischemic heart disease, myocardial infarction, stroke, arrhythmias, and arterial hypertension were more common. Moreover, the mortality from these diseases was much higher. These studies also proved that the occurrence of risk factors for cardiovascular diseases, such as hypertriglyceridemia, hypercholesterolemia, diabetes, and high body mass index (BMI) was much more frequent [4].

Cardiovascular diseases are caused by, among other factors, high levels of fibrinogen (blood coagulation factor), homocysteine, asymmetric dimethylarginine C-reactive protein (CRP), and type $B$ natriuretic propeptide. The role of vitamin $D$ is to lower the blood levels of these potential risk factors for cardiovascular disease. Many studies also show that vitamin $D$ has a positive effect on insulin secretion, inhibits the renin-angiotensin system, and inhibits cell proliferation and modulation of inflammatory processes. Through these mechanisms, vitamin $D$ is directly involved in the processes associated with the development of cardiovascular diseases [1].

One of the cardiovascular diseases that vitamin D can prevent is atherosclerosis. Vitamin D has some antiatherogenic functions, inhibiting the transformation of macrophages into foam cells, enabling the transport of HDL (high density lipoprotein) [41].

The development of atherosclerosis is caused by an inflammatory process arising from an imbalance between free radicals and antioxidants. In the human body, free radicals and antioxidants remain in a state of equilibrium, the disturbance of which is caused by so-called oxidative stress, which is one of the factors affecting the formation of atherosclerosis and coronary artery disease. Vitamin $\mathrm{D}$ has antioxidant and anti-inflammatory properties, thus maintaining the balance between free radicals and antioxidants. As a result, it plays an important role in preventing the development of atherosclerosis and coronary disease [42].

\section{Autoimmune diseases}

The immune system is responsible for protecting the body against bacteria and viruses. It does sometimes happen, however, that this system perceives the body's own cells as hostile and starts to attack them, causing what are known as autoimmune diseases. They include type 1 diabetes mellitus, hyperthyroidism and Hashimoto thyroiditis, multiple sclerosis, rheumatoid arthritis, inflammatory bowel disease, lupus erythematosus, psoriasis, vitiligo, and scleroderma [23].

Vitamin D plays an important role in the proper functioning of the immune system. It can both prevent autoimmune diseases and support their treatment. The action of vitamin $D$ is related to the presence of vitamin $D$ receptors (VDR) in many cells. Vitamin $D$ receptors are found on $T$ and $B$ lymphocytes and antigen-presenting cells (APC), which include dendritic cells, as well as monocytes and macrophages. The studies conducted so far confirm the influence of vitamin $D$ on the transcriptional activity of approximately 290 genes involved in the functioning of immune system cells [2, 23].

There are two types of $T$ lymphocytes. They are $T$ helper (Th) lymphocytes, which are characterized by the CD4 antigen, and cytotoxic T cells, which are characterized by the CD8 antigen. There are many populations of Th lymphocytes (e.g., Th1, Th2, Th9, Th17, Th22). In the context of autoimmune diseases, the population of Th17 cells, which is characterized by the production of interleukin 17 (IL-17), has a particular effect. It works by enhancing antibacterial and antifungal immunity. Many studies indicate that calcitriol inhibits the Th17 lymphocyte response, reducing the excessive production of IL-17 [23].

The active form of vitamin $D$ has a positive effect on the treatment of autoimmune diseases. These diseases are associated with an abnormal (excessive) response of the immune system [43]. Calcitriol prevents the excessive production of pro-inflammatory cytokines, while supporting the production of anti-inflammatory cytokines, thus reducing inflammatory reactions. Vitamin $D$ deficiency increases the risk of autoimmune reactions [3].

One autoimmune disease is multiple sclerosis, which is affected by genetic factors, geographic location, and dysfunctions within the immune system [2, 18]. This disease affects women much more often, as do other autoimmune diseases [43]. Vitamin D deficiency is very common in this disease, which may be caused by low food intake of vitamin $D$, as well as insufficient exposure to sunlight. Numerous studies have confirmed that vitamin $D$ supplementation may reduce the risk of multiple sclerosis, alleviate its course, 
or limit its progress [23]. It has been shown that women taking pharmaceutical preparations of vitamin $D$ in relatively high doses experience up to $40 \%$ lower risk of multiple sclerosis when compared to the women who did not use any supplementation. It has been established that by taking vitamin $D$ at the level of $1000-4000$ IU it is possible to lower the risk of developing multiple sclerosis up to $62 \%$ [44].

Autoimmune diseases associated with vitamin deficiency also include psoriasis, vitiligo, and scleroderma, which are skin diseases. On the other hand, vitamin $D$ is supplied mainly from skin synthesis, which means that its deficiencies are closely related to these diseases. The role of calcitriol in the skin is both to maintain the correct barrier (by regulating the differentiation of keratinocytes) and to act as an antibacterial and regulate the immune response. Vitamin $D$ is also important in the proper functioning of the melanocytes present in the skin. Currently, research is ongoing to determine whether vitamin $D$ deficiency is the cause of autoimmune skin diseases or is the result of impaired skin synthesis due to disease $[3,18,23]$.

The frequent occurrence of vitamin $D$ deficiencies has been confirmed in patients with Leśniowski-Crohn disease and their influence on the development and course of this disease [23]. Some studies have shown that $60 \%$ to $70 \%$ of patients may have a significant vitamin $D$ deficiency. In the case of Leśniowski-Crohn disease, the deficiency is caused by inflammatory changes, including in the small intestine. This is due to the malabsorption of vitamin $D$ from food by the intestinal mucosa, as well as the exclusion of certain foods from the patient's diet. Another reason for the insufficient supply of vitamin $D$ is the insufficient exposure of patients to sunlight due to their lifestyle [45].

\section{Cancers}

The biologically active form of vitamin $\mathrm{D}$ maintains calcium homeostasis through its action in the intestines, bones, kidneys, and parathyroid glands [7]. The process of tumor formation begins when the balance between the cycle of cell birth and death is disturbed. Insulin is involved in the production of new cells, and vitamin D contributes to the death of cells. If the level of insulin is too high and the level of vitamin $D$ is too low, the balance is disturbed. In such cases, cells multiply too quickly; the process of death of old cells is inhibited, which leads to the formation of neoplasms [7, 19].

Calcitriol activity in neoplastic diseases results from the presence of the vitamin $D$ receptor, including in the brain, breast, or colon cells [36]. The vitamin D receptor is present not only in cells and tissues involved in the regulation of calcium levels, but also in many others, including cancer cells [7]. Due to the participation of vitamin $D$ in the processes of cell proliferation, differentiation, apoptosis, and angiogenesis, its importance in neoplastic diseases is emphasized [36].
Many studies have shown a relationship between vitamin $D$ deficiency and the occurrence of certain cancers in the human body. Among them there are, for example, cancers of the colon, prostate, nipple, breast, as well as cancers of the bladder, head, neck, and lungs [10]. Epidemiological studies have reported lower incidence and mortality rates from several cancers in regions with higher solar exposure. These potential benefits of sun exposure have been attributed to vitamin $D$ because solar radiation is necessary for the skin to synthesize vitamin D [7]. Both prospective and epidemiological studies indicate that 25 -hydroxyvitamin $D$ levels below $20 \mathrm{ng} / \mathrm{mL}$ are associated with a $30 \%$ to $50 \%$ increased risk of developing colorectal, prostate, and breast cancers and with higher mortality from these cancers [36].

Studies in breast cancer patients have shown that vitamin D levels were below normal when the disease developed. It was also found that vitamin $D$ deficiency from food accelerated tumor growth [46]. A better prognosis in the case of neoplastic disease may result from increased expression of VDR, leading to a decrease in the invasiveness of cells and the risk of neoplastic metastases [36].

There is clear evidence that sun exposure increases the risk of developing all types of skin cancer, although it is also essential for vitamin D synthesis [47]. UV radiation has been recognized as an important carcinogenic factor causing cancer of the skin or lips. Researchers recommend avoiding prolonged exposure to the sun, leading to sunburn. It has been shown that people who get burns from short-term and intense exposure to the sun are more likely to develop skin cancer. The risk group also includes people with light-colored skin, hair, and eyes [48]. For this reason, it is necessary to protect the face and hands during prolonged exposure to the sun and use sun protection. It is also important to maintain the $25(\mathrm{OH}) \mathrm{D}$ level at about $20 \mathrm{ng} / \mathrm{mL}$ or higher. In many places around the world this is achievable even with brief periods of midday sun exposure in most seasons [47]. However, the relationship between the level of exposure to solar radiation and the development of various types of neoplasms is complex and perhaps depends more on the nature and duration of exposure than on the average exposure to this radiation [48].

\section{Obesity}

Another disease related to vitamin D deficiency is obesity. There are several reasons that can lead to an insufficient level of vitamin $D$ in obese people. The main reason for insufficient skin synthesis originates, among others, from the lifestyle of obese people. They tend to spend excessive time indoors, avoiding outdoor activity, thus limiting the possibility for the skin to synthesize vitamin $D$, which is the primary source of endogenous vitamin D. Exposure to the same dose of UVB radiation results in a $50 \%$ smaller increase in calcifediol 
concentration in obese people compared to people with a normal body weight $[49,50]$.

Since vitamin $D$ is stored in adipose tissue, its reduced bioavailability has been indicated as the second cause of low vitamin $D$ levels in obese people [51]. The high amount of body fat in obese individuals serves as a storehouse of vitamin D. The increased amount of vitamin $D$ necessary to saturate such a large store may therefore make obese individuals more likely to develop a serum 25(OH)D deficiency. Supplementation with vitamin $D$ in obese people requires a double dose compared to what is recommended for people of the same age with a normal body weight [9].

\section{Rickets and osteoporosis}

All cells that build the skeleton (chondrocytes, osteoblasts and osteoclasts) contain both the vitamin $D$ receptor and the enzyme CYP27B1 (1-alpha-hydroxylase) necessary for the production of the active vitamin $D$ metabolite, 1,25-dihydroxyvitamin $D$ [52]. Thus, bone itself is the main source of this vitamin's active form [21].

The direct effect of 25-hydroxyvitamin $D$ and 1,25-dihydroxyvitamin Don bonecells has been demonstrated. Calcium-phosphate homeostasis and the regulation of bone metabolism are closely related to skeletal mineralization. Maintaining this homeostasis is one of the basic functions of vitamin D [53]. Proper mineralization of bone tissue also requires an adequate supply of calcium and phosphorus, as well as undisturbed absorption of these substances in the gastrointestinal tract. In response to the decrease in serum calcium levels, its absorption in the gastrointestinal tract increases, as well as its reabsorption in the renal tubules. At the same time, calcium is mobilized from the bone through the increase in bone resorption over the coordinated function of osteoblasts and osteoclasts regulated by vitamin $D$ [21].

In relation to the skeleton, a calcitriol deficiency can have very serious consequences early in life. Vitamin $D$ deficiency results in abnormal bone mineralization, which in a later stage leads to the development of rickets in children, and in adults to disorders of bone metabolism, such as osteomalacia and osteoporosis [40]. The development of rickets in children associated with vitamin $\mathrm{D}$ deficiency is due to the low vitamin D content in breast milk and low sun exposure, especially in the first year of life. Also, deficiencies in the mother resulting from limited skin synthesis during pregnancy may result in vitamin D deficiency in the child [54]. In such children, vitamin $\mathrm{D}$ supplementation is recommended, including by feeding fortified milk. Formula-fed babies are less likely to develop vitamin $D$ deficiency, and therefore are less at risk of developing rickets, as infant formula is often supplemented with vitamin D. Consumption of one liter of modified milk containing vitamin $\mathrm{D}$ covers the need for this vitamin [11].
Vitamin D deficiency especially affects the elderly and significantly increases the risk of falls, and therefore fractures, which are responsible for the increased morbidity and mortality of the elderly [55]. Vitamin D is credited with a significant anti-fracture effect, especially in the elderly. There is also a relationship between the level of vitamin $D$ in the blood and physical fitness of adults [40]. A decreased level of $1,25(\mathrm{OH})_{2} \mathrm{D}$ causes an increase in the concentration of parathyroid hormone in blood. PTH leads to an increase in bone turnover which results in loss of bone mass. Many epidemiological studies confirm that a higher level of vitamin $D$ in the blood positively influences the increase of bone density. Bone health improvement also is caused by taking vitamin D supplements [56]. In order for vitamin $D$ to have a beneficial effect on the skeletal system, minimizing the risk of falls and fractures, scientists suggest supplementation with vitamin $\mathrm{D}$ in the amount of $700-800 \mathrm{IU}$ of cholecalciferol per day, and the concentration of $25(\mathrm{OH}) \mathrm{D}$ in the serum is best maintained at the level of $30 \mathrm{ng} / \mathrm{mL}$ [55].

\section{Depression}

Many studies confirm the relationship between vitamin D deficiency and the occurrence of mood disorders. Patients suffering from depression are in the group of people particularly vulnerable to vitamin $D$ deficiency. This state may be caused by, among others, the diet of patients (not very diversified, poor in nutritional sources of vitamin D) or low activity, both social (avoiding leaving the house) and physical (most of the time is spent indoors) [31, 57]. For example, seasonal affective disorders occur most often in winter, which is associated with lower exposure to sunlight, and thus lower levels of vitamin $D$ in the body [58].

Those most at risk of developing depressive episodes associated with vitamin $D$ deficiency include people with chronic somatic diseases, elderly patients, individuals with a history of depression, and pregnant patients [31]. Also, overweight and obese people are at risk of depressive disorders related to vitamin $D$ deficiency [40].

A study conducted in 2010 on a group of 7358 people examining the relationship between the level of plasma vitamin $D$ and the occurrence of depression showed that patients with vitamin $D$ deficiency had a higher risk of developing depressive disorders compared to the group with normal plasma vitamin D levels [57]. Hoang at al. [6] also confirmed the positive effect of vitamin $\mathrm{D}_{3}$ intake on reducing the risk of depression.

A number of studies have also been conducted to determine the effect of vitamin $D_{3}$ supplementation on the reduction of depression symptoms. In one of them, one group of subjects (overweight and obese) was supplemented with vitamin $D_{3}$ at a dose of 20,000 or 40,000 IU per week, while the other group took a placebo. There was a reduction 
in depressive symptoms in the group supplementing with vitamin $\mathrm{D}$ compared to the group that received a placebo. Another study conducted on a group of nine women (in good health) who took 5,000 IU per day for eight weeks also confirmed the positive effect of supplementation on the reduction of symptoms of depressive disorders [32]. The positive effect of vitamin $D$ has also been demonstrated in studies on people who take supplementation with vitamin $\mathrm{D}_{3}$ together with antidepressants. However, it is worth noting that the best results were obtained in patients with a significant vitamin $\mathrm{D}$ deficiency [31].

\section{Neurodegenerative diseases}

Vitamin D deficiencies are also associated with the risk of developing neurological diseases such as schizophrenia, Alzheimer disease, and cognitive impairment. Calcitriol acts in the brain via the VDR receptor, which is located in the hippocampus, hypothalamus, and cortex - that is, areas responsible for memory processes and cognition. The active form of vitamin $D$ involved in the maturation and differentiation of neurons regulates the work of glial cells and stimulates the synthesis of neurotransmitters (e.g., dopamine), and has a neuroprotective effect [59].

For this reason, vitamin $D$ may be associated with Parkinson disease, as the death of nerve cells responsible for the production of dopamine leads to this disease [12]. Vitamin D also has an antioxidant effect [60], contributing to the regulation of the toxicity of reactive oxygen species [61]. Research on the potential influence of vitamin D on Parkinson disease is carried out in the context of increased expression of the vitamin $D$ receptor gene in the blood of patients with Parkinson disease. Reduced serum levels of the major metabolite of vitamin $\mathrm{D}$, total 25-hydroxyvitamin $D$, in serum have been observed in several cross-sectional studies in patients with Parkinson disease and were more pronounced than in those with Alzheimer disease. However, it was not established whether vitamin $D$ deficiency was related to the severity of the disease. It was found that $25(\mathrm{OH}) \mathrm{D}_{3}$ attenuated the neurotoxicity of 6-hydroxydopamine, and many studies have shown an association between VDR gene polymorphisms and Parkinson disease [62].

Numerous studies confirm insufficient vitamin $D$ levels in Alzheimer patients compared to the control group [10, 12]. Studies on the effects of vitamin D on the development of Alzheimer disease indicate that this hormone is a neurosteroid that may be important in the aging process and in age-related cognitive decline. Vitamin $\mathrm{D}$ deficiency may be associated with an increased risk of Alzheimer disease and dementia, without being a causative factor [7]. Cognitive dysfunction and Alzheimer disease mainly affect the elderly, in whom vitamin $D$ deficiency results both from a weakened ability to synthesize vitamin $D$ from the sun and from a reduced supply from the diet. Reduced skin synthesis in the elderly is caused by skin thinning and deficiency of vitamin $D$ precursor (7-dehydrocholesterol). Reduced food intake, caused by chewing, biting and swallowing problems, often affecting the elderly, contributes to the improper supply of vitamin $D$ from food in the elderly [59].

\section{Virus infections}

Although it is not clear if vitamin $D$ deficiency promotes the development of viral and bacterial diseases, there is no doubt that lower levels of vitamin $D$ in the blood have been found in patients with hepatitis [63], influenza [64], tuberculosis [65], and COVID-19 [66].

Interestingly, the winter increase in influenza infections correlates with seasonal blood vitamin D levels, and supplementation of vitamin $D$ reduced the risk of developing respiratory tract infections [67, 68]. Bergman et al. [69] demonstrated that the optimal dose of vitamin D was 1000 $4000 \mathrm{IU} /$ day, especially in those living above 40 degrees latitude. Berry et al. [8] in a cohort study analysis $(n=6789)$ showed that each $2.5 \mathrm{ng} / \mathrm{mL}$ increase in 25(OH)D was associated with a $7 \%$ lower risk of respiratory infections. However, a meta-analysis of 15 randomized controlled studies analyzing the effect of vitamin $D$ supplementation on the risk of developing respiratory tract infections showed no significant risk reduction [70]. Since the heterogeneity among included studies was high in the above-mentioned meta-analysis, the obtained results should not be used to deny the potential benefits of vitamin D supplementation [53], especially since in a mouse model it has been confirmed that $25(\mathrm{OH}) \mathrm{D}_{3}$ supplementation reduces influenza virus replication [71].

Since COVID-19 is a new disease, we are not sure if vitamin $D$ can decrease the risk of this infection, so the calls for vitamin $D$ supplementation are without support from human studies, but rather are based on speculations about presumed mechanisms [72]. What is known is that $25(\mathrm{OH}) \mathrm{D}$ suppresses the cytokine storm responsible for most COVID-19 deaths [73]. Meltzer et al. [74] achieved noteworthy results in their cohort study $(n=489)$ showing that patients with an insufficient level of vitamin $D$ in the blood had a $77 \%$ greater relative risk of being tested positive for COVID-19 when compared with those with sufficient vitamin D status. Moreover, vitamin D deficiency was found in $82.2 \%$ of COVID-19 cases and $47.2 \%$ of population-based controls [75]. Furthermore, the severity of clinical outcomes from COVID-19 and mortality were reduced in patients who were vitamin D sufficient [76]. Maghbooli et al. noted that twothirds of the 235 hospitalized patients had less than $30 \mathrm{ng} /$ $\mathrm{mL}$ of vitamin $\mathrm{D}$ in their blood and only $6.3 \%$ at least $40 \mathrm{ng} /$ $\mathrm{mL}$. Besides, $9.7 \%$ and $20 \%$ who died had a $25(\mathrm{OH}) \mathrm{D}$ level above and below $30 \mathrm{ng} / \mathrm{mL}$ respectively [76]. 


\section{Future research requirements}

Based on the results of the latest research, there is no doubt that abnormal vitamin $\mathrm{D}$ levels are associated with an increased risk of various diseases. However, this issue requires clarification, especially in relation to several disease entities.

First, it cannot be conclusively stated whether vitamin D deficiencies may or may not contribute to the development of autoimmune diseases. If maintenance of adequate vitamin $D$ levels is limited due to factors such as geographic location, age, sex, or activity level, then it seems justified that vitamin $D$ supplementation in the presence of autoimmune diseases should be an integral part of the treatment.

Likewise, it has not been conclusively proven whether low vitamin $D$ levels are the cause or effect of depressive disorders. A lack of vitamin D may be just one of the many factors contributing to the development of depression. It is also necessary to determine the doses and methods of implementation that may contribute to improving the condition of patients with depression. It is believed that eating foods rich in vitamin $D$, taking dietary supplements, spending time outdoors exposed to the sun and/or exercising outdoors can significantly improve mental well-being in depressed patients, but there is no reference to this in official treatment recommendations.

Further research is also needed to elucidate the nature of vitamin $D$ storage and metabolism in obese individuals. Due to the fact that vitamin $D$ is associated with adipose tissue, it has been found that there is a possibility that it may impact the reduction of excessive body weight, although further studies in this area are necessary to explain the nature of the above-mentioned relationship.

The role of vitamin $D$ in the prevention of viral diseases is not clear, especially since some meta-analyses show no significant risk reduction in developing respiratory tract infections in those who apply vitamin D supplementation. However, since sufficient blood vitamin D levels suppress the cytokine storm responsible for most COVID-19 deaths, further studies are necessary to find a clear cause-and-effect dependence.

\section{Conclusion}

Vitamin $D$ is extremely important for the proper functioning of the body. The most widely known role of vitamin $D$ is its participation in the regulation of calcium and phosphate metabolism and bone mineralization. Vitamin D also has an antioxidant and anti-inflammatory effect and reduces the concentration of homocysteine or fibrinogen in the blood: that is, factors that carry a potential risk for cardiovascular diseases. Calcitriol, an active form of vitamin $D$, by preventing the excessive production of pro-inflammatory cytokines, and at the same time supporting the production of anti-inflammatory cytokines, also plays an important role in the prevention and treatment of autoimmune diseases. Maintaining the proper level of vitamin $D$ in the blood may also play a significant role in the prevention of the development of neurodegenerative disease, which is related to the presence of the vitamin $D$ receptor in the areas responsible for memory and cognitive functions. The proper level of $25(\mathrm{OH}) \mathrm{D}$ is also important in the prevention of neoplastic diseases, as numerous studies have indicated the participation of vitamin $D$ in the processes of cell proliferation, differentiation, apoptosis, and angiogenesis. Vitamin D supplementation may also be beneficial in patients with depressive disorders, as it has an antidepressant effect and can help prevent relapse. Obesity is also among the diseases associated with vitamin D deficiency, which is related to the storage of vitamin $D$ in adipose tissue. The greater the amount of adipose tissue, the more vitamin $D$ is needed to saturate it. Obese people usually spend more time indoors, which can also be a cause of vitamin $D$ deficiency. For these diseases, it is potentially possible to prevent and treat them by maintaining an adequate level of $25(\mathrm{OH}) \mathrm{D}$ in the blood. Depending on the needs of the individual, the appropriate concentration of vitamin $D$ can be obtained through sufficient exposure to sunlight, appropriate intake with diet, and controlled supplementation in accordance with individual recommendations.

\section{Abbreviations}

APC - antigen presenting cells, ATP - adenosine triphosphate, CTP - cytidine triphosphate, GTP - guanosine triphosphate, HDL - high density lipoprotein, IL-17 - interleukin 17, PTH - parathyroid hormone, Th - T helper lymphocytes, VDR vitamin $D$ receptors

\section{Authors' Contribution}

P.G.: research concept and design, supervising the project, revising the article critically for important intellectual content, writing the manuscript, final proofreading, and approval of the version for publication; K.I.: research concept and design, revising the article critically for important intellectual content, writing the manuscript; K.Ś:: research concept and design, analysis and interpretation of data, drafting the article, literature review. 


\section{Conflict of Interest}

The authors have no potential conflicts of interest to declare.

\section{References}

[1] Gueli N., Verrusio W., Linguanti A., Di Maio F., Martinez A., Marigliano B., Cacciafesta M. (2012). Vitamin D: Drug of the future. A new therapeutic approach. Arch Gerontol. Geriatr, 54: 222-227.

[2] Holick M.F. (2004). Sunlight and vitamin D for bone health and prevention of autoimmune diseases, cancers, and cardiovascular disease. Am. J. Clin. Nutr., 80: 1678-1688

[3] Myszka M., Klinger M. (2014). Immunomodulacyjne działanie witaminy D. Postępy Hig. Med. Dośw., 68: 865-878.

[4] Wranicz J., Szostak-Węgierek D. (2014). Health outcomes of vitamin D. Part II. Role in prevention of diseases. Rocz. Panstw. Zakl. Hig., 65: 273-279.

[5] Berk M., Sanders K.M., Pasco J.A., Jacka F.N., Williams L.J., Hayles A.L., Dodd S. (2007). Vitamin D deficiency may play a role in depression. Med. Hypotheses, 69: 1316-1319.

[6] Hoang M.T., Defina L.F., Willis B.L., Leonard D.S., Weiner M.F., Brown E.S. (2011). Association between low serum 25-hydroxyvitamin $D$ and depression in a large sample of healthy adults: The Cooper Center longitudinal study. Mayo Clin. Proc., 86: 10501055.

[7] Krishnan A.V., Trump D.L., Johnson C.S., Feldman D. (2010). The role of vitamin $D$ in cancer prevention and treatment. Endocrinol. Metab. Clin. North Am., 39: 401-418.

[8] Berry D.J., Hesketh K., Power C., Hyppönen E. (2011). Vitamin D status has a linear association with seasonal infections and lung function in British adults. Br. J. Nutr., 106: 1433-1440.

[9] PłudowskiP., Kryśkiewicz E., Karczmarewicz E. (2012). Zasady suplementacji i standardy oceny zaopatrzenia organizmu $\mathrm{w}$ witaminę D w świetle jej działania plejotropowego. Post. Nauk. Med., 25: 265-272.

[10] Szeja N. (2017). Witamina D jako związek o działaniu plejotropowym - przegląd aktualnych badań. Pomeranian J. Life Sci., 63: 128-134.

[11] Rusińska A., Płudowski P., Walczak M., Borszewska-Kornacka M.K., Bossowski A., Chlebna-Sokół D., Czech-Kowalska J., Dobrzańska A., Franek E., Helwich E., et al. (2018). Zasady suplementacji i leczenia witaminą D - nowelizacja 2018 r. Post. Neonatol., 24(1).

[12] Zdrojewicz Z., Chruszczewska E., Miner M. (2015). Wpływ witaminy D na organizm człowieka. Med. Rodz., 2: 61-66

[13] Bartoszewicz Z., Kondracka A., Jaźwiec R., Popow M., Dadlez M., Bednarczuk T. (2013). Czy umiemy wiarygodnie mierzyć stężenia klinicznie ważnych metabolitów witaminy D? Problemy i ich konsekwencje. Endokrynol. Pol., 64: 22-30.

[14] Marcinkowska M., Mickiewicz A., Fijałkowski M. (2019). Plejotropowe działanie witaminy D. Choroby Serca i Naczyń, 16: 45-52.
[15] Jones G. (2008). Pharmacokinetics of vitamin D toxicity. Am. J. Clin. Nutr., 88: 582-586.

[16] French C.B., McDonnell S.L., Vieth R. (2019). 25-Hydroxyvitamin $D$ variability within person due to diurnal rhythm and illness: A case report. J. Med. Case Rep., 13: 29.

[17] Walicka M., Jasik A., Paczyńska M., Wąsowski M., Tałałaj M., Marcinowska-Suchowierska E. (2019). Niedobór witaminy D problem społeczny. Post. Nauk Med., 32: 14-22.

[18] Kuryłowicz A., Bedna.rczuk T., Nauman J. (2007). Wpływ niedoboru witaminy D na rozwój nowotworów i chorób autoimmunologicznych. Endokrynol. Pol., 58: 140-152.

[19] Zaidi S. (2015). Power of Vitamin D: A Vitamin D Book That Contains the Most Scientific, Useful And Practical Information About Vitamin D - Hormone D. CreateSpace Independent Publishing Platform.

[20] Carvallo L., Henríquez B., Paredes R., Olate J., Onate S., van Wijnen A.J., Lian J.B., Stein G.S., Stein J.L., Montecino M. (2008). 1alpha,25-dihydroxy vitamin D3-enhanced expression of the osteocalcin gene involves increased promoter occupancy of basal transcription regulators and gradual recruitment of the 1-alpha,25dihydroxy vitamin D3 receptor-SRC-1 coactivator complex. J. Cell Physiol., 214: 740-749.

[21] Walicka M., Czerwińska E., Marcinowska-Suchowierska E. (2012). Witamina D - wpływ na kość. Post. Nauk Med., 25: 232236.

[22] Glibowski P.: Dietary factors affecting osteoporosis and bone health in the elderly. In: Molecular Basis of Nutrition and Aging, Ed. (2016). M. Malavolta, E. Mocchegiani, Amsterdam: Academic Press, 345-354.

[23] Lisowska K.A., Bryl E. (2017). Rola witaminy D w rozwoju chorób autoimmunologicznych. Postępy Hig. Med. Dośw., 71: 797-810.

[24] Grant W.B., Garland C.F. (2006). The association of solar ultraviolet $B(U V B)$ with reducing risk of cancer: Multifactorial ecologic analysis of geographic variation in age-adjusted cancer mortality rates. Anticancer Res., 26: 2687-2699.

[25] Osińska M., Pazik A., Krasuska K., Zadykowicz R., Kazberuk A., Rysiak E. (2017). Rola niedoboru witaminy D w patogenezie chorób nowotworowych. Farmacja Współcz., 10: 100-106.

[26] Wang T.J., Pencina M.J., Booth S.L., Jacques P.F., Ingelsson E., Lanier K., Benjamin E.J., D'Agostino R.B., Wolf M., Vasan R.S. (2008). Vitamin D deficiency and risk for cardiovascular disease. Circulation, 117: 503-511.

[27] Judd S.E., Tangpricha V. (2009). Vitamin D deficiency and risk for cardiovascular disease. Am. J. Med. Sci., 338: 40-44.

[28] Scragg R., Sowers M., Bell C., Third National Health and Nutrition Examination Survey. (2004). Serum 25-hydroxyvitamin D, diabetes, and ethnicity in the Third National Health and Nutrition Examination Survey. Diabetes Care, 27: 2813-2818.

[29] Krasińska A., Skowrońska B. (2014). Znaczenie witaminy D u pacjentów z nadmierną masą ciała — nowe zasady suplementacji. Forum Zaburzeń Metabol., 5: 63-70. 
[30] Jorde R., Sneve M., Figenschau Y., Svartberg J., Waterloo K. (2008). Effects of vitamin D supplementation on symptoms of depression in overweight and obese subjects: Randomized double blind trial. J. Intern. Med., 264: 599-609.

[31] Stefanowski B., Antosik-Wójcińska A., Święcicki Ł. (2017). Wpływ niedoboru witaminy D3 na poziom nasilenia objawów depresyjnych. Przegląd aktualnych badań. Psychiatr. Pol., 51: 437-454.

[32] Spiro A., Buttriss J.L. (2014). Vitamin D: An overview of vitamin D status and intake in Europe. Nutr. Bull., 39: 322-350.

[33] Holick M.F. (2007). Vitamin D deficiency. N. Engl. J. Med., 357: 266-281.

[34] Hossein-Nezhad A., Holick M.F. (2013). Vitamin D for health: A global perspective. Mayo Clin. Proc., 88: 720-755.

[35] Tukaj C. (2008). Właściwy poziom witaminy D warunkiem zachowania zdrowia. Postępy Hig. Med. Dośw., 62: 502-510.

[36] Grygiel-Górniak B., Puszczewicz M. (2014). Witamina D - nowe spojrzenie w medycynie i reumatologii. Postępy Hig. Med. Dośw., 68: 359-368.

[37] Khan Q.J., Fabian C.J. (2010). How I treat vitamin D deficiency. J. Oncol. Pract., 6: 97-101.

[38] Sizar O., Khare S., Goyal A., Bansal P., Givler A. (2020). Vitamin $D$ deficiency. Treasure Island: StatPearls Publishing.

[39] Jones A.N., Hansen K.E. (2009). Recognizing the musculoskeletal manifestations of vitamin D deficiency. J. Musculoskelet. Med., 26: 389-396.

[40] Gadomski, A. (2017). Skutki niedoboru witaminy D w organizmie człowieka. Nowa Pediatr., 1: 34-37.

[41] Mozos I., Marginean O. (2015). Links between vitamin D deficiency and cardiovascular diseases. Biomed Res. Int., 2015: 109275.

[42] Wiśniewski P., Nessler J. (2016). Witamina D a układ krążenia. Kardiol. Inwazyjna, 11: 62-68.

[43] Stasiołek M., Mycko M., Stelmaj K. (2005). Patogeneza stwardnienia rozsianego. Pol. Przegl. Neurolog., 1: 92-98.

[44] Harandi A.A., Harandi A.A., Pakdaman H., Sahraian M.A. (2014). Vitamin D and multiple sclerosis. Iran J. Neurol., 13: 1-6.

[45] Ananthakrishnan A.N. (2016). Vitamin D and inflammatory bowel disease. Gastroenterol. Hepatol., 12: 513-515.

[46] Williams J.D., Aggarwal A., Swami S., Krishnan A.V., Ji L., Albertelli M.A., Feldman B.J. (2016). Tumor autonomous effects of vitamin $\mathrm{D}$ deficiency promote breast cancer metastasis. Endocrinology, 157: 1341-1347.

[47] Wyatt C., Neale R.E., Lucas R.M. (2015). Skin cancer and vitamin D: An update. Melanoma Manag., 2: 51-61.

[48] Nowicka G. (2008). Promieniowanie słoneczne a witamina D i nowotwory skóry. Studia Ecologiae et Bioethicae, 6: 9-14.

[49] Carrelli A., Bucovsky M., Horst R., Cremers S., Zhang C., Bessler M., Schrope B., Evanko J., Blanco J., Silverberg S.J., Stein E.M. (2017). Vitamin D storage in adipose tissue of obese and normal weight women. J. Bone Miner. Res., 32: 237-242.

[50] Wąsowski M., Czerwińska E., Marcinowska-Suchowierska E. (2012). Otyłość - stan predysponujący do niedoborów witaminy D. Post. Nauk Med., 25: 258-264.
[51] Wortsman J., Matsuoka L.Y., Chen T.C., Lu Z., Holick M.F. (2000). Decreased bioavailability of vitamin $D$ in obesity. Am. J. Clin. Nutr., 72: 690-693.

[52] Bikle D.D. (2012). Vitamin D and bone. Curr. Osteoporos. Rep., 10: 151-159.

[53] Kmieć P., Sworczak K. (2017). Korzyści i zagrożenia wynikające z suplementacji witaminą D. Forum Med. Rodz., 11: 38-46.

[54] Holick M.F. (2006). High prevalence of vitamin D inadequacy and implications for health. Mayo Clin. Proc., 81: 353-373.

[55] Jasik A., Tałałaj M., Paczyńska M., Walicka M., Wąsowski M., Marcinkowska-Suchowierska E. (2008). Witamina D i osteoporoza. Post. Nauk. Med., 32: 8-13.

[56] Granda D., Żyfka-Zagrodzińska A., Renc-Smolewska P., Szmidt M., Wierzbicka E., Brzozowska A. (2019). Witamina D u osób starszych - funkcje, ryzyko niedoboru i wiedza seniorów. Kosmos. Probl. Nauk Biol., 68: 283-292.

[57] May H.T., Bair T.L., Lappé D.L., Anderson J.L., Horne B.D., CarIquist J.F., Muhlestein J.B. (2010). Association of vitamin D levels with incident depression among a general cardiovascular population. Am. Heart J., 159: 1037-1043.

[58] Józefowicz O., Rabe-Jabłońska J., Bogaczewicz J., Woźniacka A. (2009). Rola witaminy D3 w patogenezie zaburzeń psychicznych. Psychiatr. Psychol. Klin., 9: 200-206.

[59] Drąg J., Goździalska A., Jaśkiewicz J. (2015). Niedobory witaminy $D$ a konsekwencje zdrowotne. Państwo i Społeczeństwo, 15: 113-126.

[60] Annweiler C., Dursun E., Féron F., Gezen-Ak D., Kalueff AV., Littlejohns T., Llewellyn D.J., Millet P., Scott T., Tucker K.L., et al. (2015). Vitamin D and cognition in older adults: Updated international recommendations (Review). J. Intern. Med., 277: 45-57.

[61] Schlögl M., Holick M.F. (2014). Vitamin D and neurocognitive function. Clin. Interv. Aging, 9: 559-568.

[62] Ding H., Dhima K., Lockhart K.C., Locascio J.J., Hoesing A.N., Duong K., Trisini-Lipsanopoulos A., Hayes M.T., Sohur S., Wills A.M., et al. (2013). Unrecognized vitamin D3 deficiency is common in Parkinson disease: Harvard Biomarker Study. Neurology, 81: 1531-1537.

[63] Udomsinprasert W., Jittikoon J., Sukkho S., Pojarassangkul N., Sangroongruangsri S., Chaikledkaew U. (2020). Decreased circulating vitamin $D$ reflects adverse outcomes of hepatitis $C$ virus infection: A systematic review and meta-analysis. J. Infect., 81: 585-599.

[64] Jones B.G., Oshansky C.M., Bajracharya R., Tang L., Sun Y., Wong S.S., Webby R., Thomas P.G. Hurwitz J.L. (2016). Retinol binding protein and vitamin $D$ associations with serum antibody isotypes, serum influenza virus-specific neutralizing activities and airway cytokine profiles. Clin. Exp. Immunol., 183: 239-247.

[65] Ginde A.A., Mansbach J.M., Camargo C.A. Jr. (2009). Association between serum 25-hydroxyvitamin $D$ level and upper respiratory tract infection in the third national health and nutrition examination survey. Arch. Intern. Med., 169: 384-390. 
[66] Grant W.B., Lahore H., McDonnell S.L., Baggerly C.A., French C.B., Aliano J.L., Bhattoa H.P. (2020). Evidence that vitamin D supplementation could reduce risk of influenza and COVID-19 infections and deaths. Nutrients, 12: 988.

[67] Marik P.E., Kory P., Varon J. (2020). Does vitamin D status impact mortality from SARS-CoV-2 infection? Med. Drug Discov., 6: 100041.

[68] Martineau A.R., Jolliffe D.A., Hooper R.L., Greenberg L., Aloia J.F., Bergman P., Dubnov-Raz G., Esposito S., Ganmaa D., Ginde A.A., et al. (2017). Vitamin D supplementation to prevent acute respiratory tract infections: Systematic review and meta-analysis of individual participant data. BMJ, 15: i6583.

[69] Bergman P., Lindh Å.U., Björkhem-Bergman L., Lindh J.D. (2013). Vitamin D and respiratory tract infections: A systematic review and meta-analysis of randomized controlled trials. PLoS One, 8: e65835.

[70] Vuichard Gysin D., Dao D., Gysin C.M., Lytvyn L., Loeb M. (2016). Effect of vitamin D3 supplementation on respiratory tract infections in healthy individuals: A systematic review and metaanalysis of randomized controlled trials. PLoS One, 11: e0162996.

[71] Hayashi H., Okamatsu M., Ogasawara H., Tsugawa N., Isoda N., Matsuno K., Sakoda Y. (2020). Oral supplementation of the vitamin $\mathrm{D}$ metabolite $25(\mathrm{OH}) \mathrm{D}_{3}$ against influenza virus infection in mice. Nutrients, 12: 2000.

[72] Lanham-New S.A., Webb A.R., Cashman K.D., Buttriss J.L., Fallowfield J.L., Masud T., Hewison M., Mathers J.C., Kiely M., Welch A.A., et al. (2020). Vitamin D and SARS-CoV-2 virus/COVID-19 disease. BMJ Nutr. Prev. Health, 3: 106-110.

[73] Ahmed F. (2020). A network-based analysis reveals the mechanism underlying vitamin $D$ in suppressing cytokine storm and virus in SARS-CoV-2 infection. Front. Immunol., 11: 590459.

[74] Meltzer D.O., Best T.J., Zhang H., Vokes T., Arora V., Solway J. (2020). Association of vitamin D status and other clinical characteristics with COVID-19 test results. JAMA Netw. Open., 3: e2019722.

[75] Hernández J.L., Nan D., Fernandez-Ayala M., García-Unzueta M., Hernández-Hernández M.A., López-Hoyos M., Muñoz-Cacho P., Olmos J.M., Gutiérrez-Cuadra M., Ruiz-Cubillán J.J., et al. (2021). Vitamin D status in hospitalized patients with SARS-CoV-2 infection. J. Clin. Endocrinol. Metab., 106: e1343-e1353.

[76] Maghbooli Z., Sahraian M.A., Ebrahimi M., Pazoki M., Kafan S., Tabriz H.M., Hadadi A., Montazeri M., Nasiri M., Shirvani A., Holick M.F. (2020). Vitamin D sufficiency, a serum 25-hydroxyvitamin D at least $30 \mathrm{ng} / \mathrm{mL}$ reduced risk for adverse clinical outcomes in patients with COVID-19 infection. PLoS One, 15: e0239799. 